\title{
Have Child Custody and Right of Access been Overlooked under the Domestic Violence Act 1994 in Malaysia?
}

\author{
Dr. Daleleer Kaur Randawar
}

Faculty of Law, Universiti Teknologi MARA, (UiTM) Shah Alam, Selangor, Malaysia; dolly_uitm@yahoo.com

\author{
Doi:10.5901/mjss.2016.v7n5p11
}

\section{Abstract}

The family can be considered as a place of refuge from stress and strains of the outside world. This may be true for some but sometimes the home can also be a very dangerous and unsafe place for women and children ${ }^{1}$. Besides wife battering and abuse, child abuse also occurs within the family. A large number of children are also abused by those whom they love and trust. These abusers include a parent, a stepparent, a grandparent, a close relative regardless of their age. In Malaysia, the Domestic Violence Act 1994 (Act No. 521) was passed in early 1994 by the Malaysian Parliament to curb violence within a home. ${ }^{2}$ This Act offers battered women and children protection from the abuser in the form of protective orders and provides for compensation and counseling to be made available to them. ${ }^{3}$ However, the Domestic Violence Act 1994 has failed to consider an important aspect pertaining to children i.e. that of child custody and right of access or visitation. This is important as some abusive husbands exploit their right to custody of children and right of access or visitation as a way to inflict abuse and gain access to battered wives. However, what is overlooked is that the child is left in the custody of and subject to right access or visitation by the abusive parent. Many countries have addressed and included provisions pertaining these matters in their legislation dealing with domestic violence. This article will critically analyze the statutory provisions that govern custody and right of access or visitation of children in Malaysia generally and in particular to determine whether custody and access or visitation orders should be made with a view to protect the children from the abusive parent(s). In addition, this article will also suggest legislative reforms. The research methodologies applied in this article will be the analysis of primary and secondary materials and will also involve a comparative study of other comparable jurisdictions. Thus, statutory provisions, case law and other legal and non-legal literature will be examined in this article.

Keywords: domestic violence, children, custody, access, visitation.

\section{Introduction}

The problem of wife battering and child abuse is not a new one. (Randawar, D. K. \& Jayabalan, S., 2015) Since this offence happens within the walls of a home, between a husband and wife, it is usually viewed as 'private family matter' and at times these problems are just swept under the carpet and such cases are often never detected or reported. (Randawar, D. K. \& Jayabalan, S., 2015) Diduck, A. \& Kaganas, F., (2006) believes that perhaps one of the crucial factors in the construction of domestic violence as a social problem has been the challenge to the conception of the family as a private haven. Douglas, G., (2001) explains that instead of the home being seen as a haven of peace and tranquility, it is revealed as a place of disharmony and potential danger. Children have the right to be protected from being hurt and ill-treated, physically or psychologically. The law should ensure that children are properly cared for and protect them from violence, abuse and neglect by their parents, or anyone else who looks after them.

Despite the availability of the Domestic Violence Act 1994 (DVA 1994), which has been designed to provide protection to battered wives and children, it has fail to highlight the concerns on family law rights pertaining to child custody and right of access or visitation which in fact have been included in some countries' legislations. The Malaysian DVA 1994 has in fact provided for provisions pertaining to compensation and counselling, except for provision on temporary custody and right of access or visitation of children. This paper highlights that although an Act which in particular deals with domestic violence exists, in reality importance is not given to matters pertaining to temporary custody

${ }^{1}$ Daleleer Kaur Randawar, "A Socio-Legal Study on Adequacy of Laws in providing protection for battered wives in Malaysia", A Thesis submitted in fulfilment of the requirement for the degree of Doctor of Philosophy in Law, International Islamic University Malaysia (IIUM), July 2012

2 Malaysian Domestic Violence Act 1994, (Act 521) [1.6.1996-PU(B) 226/1996]; The Malaysian Domestic Violence was amended and came into force on 20.2.2012-PU(B) 56/2012

3 Ibid 
order and right of access or visitation of a child unless a different proceeding such as divorce or judicial separation is initiated under family laws, namely the Law Reform (Marriage \& Divorce) Act 1976 (LRA 1976) ${ }^{4}$ and Islamic Family Law (Federal Territory) Act 1984 (IFLA 1984)5. These provisions are not available under the DVA 1994.

Therefore, this article will also look into the aspect of law pertaining to child custody and right of access or visitation that require serious attention. This article will also look into certain theories involving domestic violence which directly relates to children. A general view of the law on custody under the LRA 1976 will also be analysed. This article will also look at other jurisdictions where the issue on child custody and right of access or visitation have been broadly and significantly dealt with under the purview of the domestic violence act.

\section{Research Methodology}

This paper uses doctrinal legal research to analyze the law pertaining to custody rights in the Domestic Violence Act 1994. Article will be primarily based on library research, wherein a qualitative analysis is adopted to assess ramifications and improvements of the laws regulating custody rights into the domestic violence law in Malaysia. Reference comprises extensive literature gathered from textbooks and articles, seminars papers, relevant statutes and decided cases of the courts. Valid sources from the internet are also referred to in keeping up with the latest development of the matter.

Comparative analysis is adopted by comparing and contrasting the applicable laws in selected jurisdictions including in order to improvise on the shortcomings and deficiencies of the laws of domestic violence applicable in Malaysia. External reference will be made to the laws in certain developed and developing countries. Reference will be made to laws in Philippines, India, and Cambodia as these three countries are part of emerging Asian countries with different economic status and are related closely to the same legal milieu in Malaysia. Article focuses on analyzing the differences, special and unique features of the custody and visitation rights under the domestic violence law in these selected jurisdictions.

\section{Theories on Family Violence}

Patterns of family violence appear to be learned in families, where if a child is abused, that child (when he becomes an adult and a parent) is more likely to abuse his children. Dutton, D. G. (2001) is of the opinion that a man who was abused as a child is more likely to batter his wife, as his repressed emotions will sabotage his relationships, and he may become violent with family members, just as his father did with him. However, Lockton, D. and Ward, R. (1997) opine that experiencing violence as a child, either as a witness or a victim, may, in some cases, lead to an acceptance of violence as a norm, but it is suggested that this is only a contributory factor. Dobash, R. E. \& Dobash, R. (1979) further suggest that it is wrong to assume that all children of wife-beaters, or any of them, for that matter, will learn to accept or imitate the violent behavior they see and therefore will grow up violent themselves or become victims of violence.

There are many possible explanations for every form of crime that is committed, some which in fact make sense and some less so. It is important to study the theories and examine the causes and effects of domestic crimes, as this will influence the actions that are perceived to address the problem. For example, if wife battering is a result of gender inequality, then measures to improve the status of women should be seriously considered; and if it is due to the individual's pathology, then therapeutic prevention measures should be taken to curb this abuse. This study of theories will help the public to understand why the abuser or perpetrator committed violence and also assist the criminal justice system to respond better with improved prevention and sanctioning strategies.

There are numerous theories on the causes of family violence and each theory approaches family violence from a variety of perspectives with different implications for policies aimed at eliminating the problem. Although very little literature has been published in Malaysia to contextually study the theories of wife abuse, many international discourses have attempted to explain why husbands become violent towards their wives. (Hashim, I. H. M. \& Endut, N., 2004)

\subsection{Social Learning Theory}

The Social Learning Theory is one of the most popular explanatory frameworks for violence against women, suggesting that individuals learn how to behave through both experience in and exposure to violence. (Jasinski, J. L., 2001) According to the Social Learning Theory, people are not born with violent tendencies but they learn them through their

\footnotetext{
${ }^{4}$ Act 164

${ }^{5}$ Act 303
} 
environment and life experiences. (Gosselin, D. K., 2003) Deviance is learned in the same manner as normative behavior: the process of learning is through communication with others and includes motives, drives, attitudes, and rationalizations on the commission of crime. (Gosselin, D. K., 2003).

The frequency and duration of violence in one's environment will influence the learning experience. (Gosselin, D. K., 2003) The manner in which a person perceives a situation form his or her own viewpoint will affect the response and this becomes the reality under which the person will operate in the future and perceive similar events. (Gosselin, D. K., 2003) Those who physically abuse family members are thought to have witnessed abuse by others and have incorporated it into their own patterns of behavior. (Mignon, S. I., Larson, C. J., and Holmes, W. M., 2002) This theory helps to explain why physical and sexual abuse tends to represent the behavior of multiple members within a family (Mignon, S. I., Larson, C. J., and Holmes, W. M., 2002).

The Social Learning Theory is accomplished by two important mechanisms: modeling and reinforcement. (Wallace, $H_{., 1999)}$ Modeling is an important tool in the learning behavior as children learn by watching and imitating others and this will result in children adopting the behavior they observe in adults, including aggressive acts. (Wallace, H., 1999) Reinforcement occurs when a certain behavior is rewarded and another behavior is punished. (Wallace, H., 1999)

The priority principle, association, reinforcement, modeling and exposure to conforming and deviant definitions occurring within the family during childhood, and such antisocial conduct as aggressiveness, lying, and cheating learned in early childhood, occur prior to marriage and have both direct and selective effects on later delinquent and criminal behavior and associations. (Akers, R. L., 2002).

\subsection{Intergenerational Transmission Theory}

According to this theory, abusive behavior is handed down from generation to generation as an appropriate way to deal with conflict: violence begets violence. (Gosselin, D. K., 2003) This does not suggest that battering tendencies are inherited; rather, they are experienced as people who observe violence in the home as children are more likely to resort to battering in their own relationships later in life. (Gosselin, D. K., 2003) If a child is abused, he or she learns that it is acceptable if not a normal way to achieve his or her goal and this child becomes an abusive adult toward his or her spouse and often toward his or her own children. (Gosselin, D. K., 2003).

The Intergenerational Transmission of Violence Theory views battering as a learned behavior that is passed down from one generation to another within the family system. (Belknap, J., 2001) In applying this theory, it is important to acknowledge that experiential learning is likely to be different for males and females; while both males and females may learn that physical conflict is a legitimate response to family or interpersonal conflict, males may learn to be the oppressors, whereas females learn to be the victims. (Belknap, J., 2001).

Franklin, C. A., (2010) also believes that the intergenerational transmission of violence approach, children may also be the recipients of violence, and, for some, these experiences pave the way for future violence in adulthood. Specifically, children see that parents use violence in frustrating situations and to cope with difficulty.

Study conducted suggest that childhood behavior problems are among the most robust predictors of partner violence, that conduct disorder appears to mediate the effect of child abuse, and that exposure of violence between parents and power assertive punishment during childhood significantly increase the risk for using violent conflict resolution within intimate relationship. (Ehrensaft, M. K., Cohen, P., Brown, J., Smailes, E., Chen, H., Johnson, J. G., 2003).

However, the Theory of Intergenerational Transmission of Violence has received criticisms, too. For instance, it is possible that living in a violent home may result in an adult survivor's strong commitment to disallow violence in her or his own home, as adult survivors of homes where woman battering has occurred may not all behave in a similar manner. (Belknap, J., 2001) While there are some implications for condoning violence if one grows up with it, the overall impact on violent behavior in the future is unclear. (Belknap, J., 2001)

Applying behavioral genetic methods to the study of intimate partner violence can provide an explicit test of the social learning theory as it relates to the intergerational transmission of violence in intimate relationships. Currently, the assumptions is that violence transmit through the generations because children learn violence from their parents. However, without a behavioral genetic analysis of the familial resemblance for intimate partner violence, it cannot be assumed that this familial resemblance is due solely environmental influences, as social laerning theory would imply. (Hines, D.A., \& Saudino, K.J., 2002).

Different explanations are given on the types of theories that are available. Each writer or scholar has explained these theories from a different perspective. However, in reality some theories are closely related to one another. For example, according to the Social Learning Theory, people are not born with violent tendencies but they learn them 
through their environment and life experiences. Similarly, the Intergenerational Transmission of Violence Theory views battering as a learned behavior that is passed down from one generation to another within the family system. Simply put, these theories suggest that violence is learned within a family, in which children of these families may learn the behavior from their parents.

\section{Custody and Right of Access under Family Law-The Law Reform (Marriage and Divorce) Act 1976 (LRA 1976)}

The objective of the LRA 1976 is to regulate marriage and divorce. Under the LRA 1976, section 103 provides remedy for victims of domestic violence, especially the wife, in which the court shall have power during the pendency of any matrimonial proceedings or on or after the grant of a decree or divorce, judicial separation or annulment, to order any person to refrain from forcing his or her society on his or her spouse or former spouse and form other acts of molestation. ${ }^{6}$

Under the LRA 1976 issue pertaining to protection of children has been broadly dealt with under Part V111. The court under section 88(1) of the LRA 1976 may at any time by order place a child in the custody of his or her father or his or her mother, and also under exceptional circumstances to any other relative of the child. In deciding in whose custody a child should be placed, section 88(2) (a) and (b) of the LRA 1976 states that the paramount consideration shall be the welfare of the child, in which the courts shall have regard to the wishes of the parents of the child and the wishes of the child, where he or she is of an age to express an independent opinion. The provision reads as:

Section 88(2) In deciding in whose custody a child should be placed the paramount consideration shall be the welfare of the child and subject to this the court shall have regard-

(a) to the wishes of the parents of the child; and

(b) to the wishes of the child, where he or she is of an age to express an independent opinion ${ }^{7}$

With regards to right of access, under section 89(2)(c) the court may provide for a child to visit a parent deprived of custody or any member of the family of a parent as the court may consider reasonable. Likewise, under section 89(2)(d) LRA 1976, the court may provide a parent or any member of the family of a parent the right of access to the child at such times and with such frequency as the court may consider reasonable. The provision reads as:

Section 89(1): An order for custody may be made subject to such conditions as the court may think fit to impose and subject to such conditions, if any, as may from time to time apply, shall entitle the person given custody to decide all questions relating to the upbringing and education of the child.

Section 89(2): Without prejudice to the generality of subsection (1), an order for custody may-

(c) provide for the child to visit a parent deprived of custody or any member of the family of a parent who is dead or has been deprived of custody at such times and for such periods as the court may consider reasonable;

(d) give a parent deprived of custody or any member of the family of a parent who is dead or has been deprived of custody the right of access to the child at such times and with such frequency as the court may consider reasonable;

It is seen that the court when making custody and right of access takes into consideration the welfare of the child. Generally, right of access or visitation is awarded to the non-custodial parent, as this is a parental right which is necessary to both the parent. Only in exceptional circumstances will a non-custodial parent be denied the right of access or visitation.

Violent and dangerous behavior, as well as irresponsible behaviour of the parties, will be taken into account in determining custody and right of access or visitation disputes as these will certainly affect the interests of the child. In $L v$ $S$ (2002) 7 MLJ 584, the court came to the opinion considering the husband's impulsive, violent and dangerous behaviour and his being diagnosed as a 'parasuicide', it would not be in the best interest and welfare of the child that he should, at this early and critical stage of his life, be brought up in an environment that would expose him to the risks posed by the husband's volatile temperament. Having considered all the factors and giving paramount consideration to the welfare of the child, the custody, care and control of the child should be awarded forthwith to the wife subject to reasonable access to the husband.

Similarly, in Sivajothy a/p K Suppiah v Kunathasan a/l Chelliah, (2000) 6 MLJ 48, the father who was a violent, abusive and unreasonable person, was not entitled to custody. It was held to be in the best interest of the welfare of the children for them to continue to remain together in the custody of the mother. Thus, the mother was granted sole and full custody, care and control of the children with reasonable access to the father. In Loh Kon Fah v Lee May Lian (1976) 2

\footnotetext{
6 The Law Reform (Marriage and Divorce) Act 1976 (Act 164)
}

7 Ibid 
MLJ 199, the court ordered the custody of the three children to the mother with unlimited access to the father.

\section{Comparative Child Custody and Right of Access or Visitation in Selected Jurisdiction}

Another important aspect which needs to be considered and included in a Protection Order is the provision involving child custody and right to access or visitation. This is important as some abusive husbands exploit custody of children and right to access or visitation as a way to inflict abuse and gain access to battered wives. Many countries have addressed and included this provision pertaining to child custody and right to access or visitation in their Acts.

On this note, in the Republic of the Philippines, Republic Act No. 9262, under section 8(f) of the Anti-Violence Against Women and their Children Act 2004, the Protection Order issued by the court also includes reliefs in granting temporary or permanent custody of child/children to the petitioner. ${ }^{8}$ In granting this order the court under section $8(\mathrm{~g})$ of the Anti-Violence Against Women and their Children Act 2004, will direct the husband to provide support to the woman and/or her child if entitled to legal support. ${ }^{9}$ What is interesting to note is the court will order an appropriate percentage of the income or salary of the respondent to be withheld regularly by the respondent's employer and to be automatically remitted to the victim. Failure of this will result in the respondent or his employer liable for indirect contempt of court. The provision reads:

......The protection orders that may be issued under this Act shall include any, some or all of the following reliefs:

f. Granting a temporary or permanent custody of a child/children to the petitioner

g. Directing the respondent to provide support to the woman and/or her child if entitled to legal support. Notwithstanding other laws to the contrary, the court shall order an appropriate percentage of the income or salary of the respondent to be withheld regularly by the respondent's employer for the same to be automatically remitted directly to the woman. Failure to remit and/or withhold or any delay in the remittance of support to the woman and/or her child without justifiable cause shall render the respondent or his employer liable for indirect contempt of court;

The above provision is helpful as it not only provides a custody order but also goes on further by protecting the financial needs of the battered wives and their children. For a better sense of security and to avoid default of such payments by the husband, a percentage of the salary will be automatically remitted to the battered wives. This provision imposes a sense of responsibility upon the husband and even the husband's employer.

Also, in the Republic of the Philippines, under section 3(C) of the Anti-Violence Against Women and their Children Act 2004 any form of unlawful or unwanted deprivation of the right to custody and/or visitation to a common child are also deemed as psychological/violence abuse.

Under section 21 of the Indian Protection of Women from Domestic Violence Act 2005 the Magistrate may grant a temporary custody order during the application of the Protection Order. ${ }^{10}$ Visitation rights may also be granted by the courts provided that the visitation rights granted are not harmful to the children. If the Magistrate is of the opinion that any visit of the respondent may be harmful to the interests of the child or children, the Magistrate shall refuse to allow such visit. The provision reads:

21. Custody orders- Notwithstanding anything contained in any other law for the time being in force, the Magistrate may, at any stage of hearing of the application for protection order or for any other relief under this Act grant temporary custody of any child or children to the aggrieved person or the person making an application on her behalf and specify, if necessary, the arrangements for visit of such child or children by the respondent.

Provided that if the Magistrate is of the opinion that any visit of the respondent may be harmful to the interests of the child or children, the Magistrate shall refuse to allow such visit. ${ }^{11}$

Likewise, even in Cambodia, under Article 25 of the Law on the Prevention of Domestic Violence and the Protection of Victims, the court when issuing a protection order, can make the additional measures by making a decision on the custody of the children and the rights to visit the children by paying the highest attention to the rights and interests of the

\footnotetext{
${ }^{8}$ R.A 9262 signed on 2 March 2004

${ }_{9}$ R.A. 9262 signed on 2 March 2004

${ }^{10}$ An Act of the Parliament of India brought into force by the Indian government from 26 October 2006.

11 Ibid
} 
children. ${ }^{12}$ This following additional measures can be taken if the court knows it is necessary to protect or provide the safety, health and welfare of the victim.

As illustrated above, the issue of custody order is included by several countries in their Domestic Violence Acts. The countries or states above clearly explain the Magistrate's rights to allow temporary or permanent custody order to the victim. More interestingly, it even directs the perpetrator to provide legal support which in fact can be automatically remitted to the victim from the perpetrator's salary.

\section{Conclusion}

An undeniable fact is that when violence occurs, children suffer from the violence directly or indirectly. The issue pertaining to welfare of children should also be of primary concern for all parties involved. Freeman, M., (2007) also stressed that domestic violence has serious implications for the safety and well-being of children.

This emphasis will find support from the Philippines Anti-Violence Against Women and their Children Act wherein the provision not only provides for custody order but goes on further in providing financial support to the battered wives and children. The law enforces a percentage of the husband's salary to be automatically remitted to the battered wives. A mother who obtains the custody of the child added with financial security will face less financial stress. Financial assistance should also help victims to recover faster from the trauma suffered from the abuse.

Likewise, even in Cambodia and India provisions pertaining to custody order and visitation rights may be included when issuing the Protection Order. However, when such orders are made the rights and interest of the children must be considered. Custody granted to a non-violent spouse will allow a child to grow in a safe and happy environment.

Concerns on family law rights pertaining to child custody and right to access or visitation have been included in some countries' legislations. All domestic violence cases should be handled accordingly regardless of the severity of the offence and should be treated equally like other crimes. It is important to adopt some of the best practices employed in some regions and to use them as a model in lobbying and advocating for legislations that will directly benefit and protect the rights of women and children exclusively.

Inclusion of custody and visitation orders in the Malaysian Domestic Violence Act will allow simpler court proceedings. There will be no necessity to apply for a separate proceeding such as divorce or judicial separation to determine custody and maintenance of a child in a family. Since a divorce proceeding usually ends a marriage, inclusion of custody and visitation provisions in the Domestic Violence Act may likelihood reconcile a family. Abusers who feels remorse about their action may want to reunite and restore family relations again.

Hence, a considerable degree of importance needs to be placed on the issue of custody and right to access or visitation in domestic violence cases. Courts should be given the power to grant temporary custody of children and right to access or visitation in applications for protection orders, to keep in mind the best interests of the child. Right to access or visitation should be temporarily denied when there is a history of abuse, not only because the child may be at risk of violence or sexual abuse but because contact with the parents needs to be limited. (Schneider, E. M., 2008) In such situations, family visitation centers can be opened to facilitate right to access or visitation and not terminate parental rights.

Therefore, it is necessary to amend the Malaysian Domestic Violence Act to include provisions pertaining to temporary child custody and right to access or visitation in the Domestic Violence Act. Many countries have provided for temporary custody order and right to access or visitation of a child as early as the application for an Interim Protection Order (IPO). In granting this order, the court has also directed the husband to provide support to the child. The court should consider on making such temporary orders pertaining to child custody and right to access or visitation in order to inhibit the begining of Social Learning Theory, people are not born with violent tendencies similarly the Intergenerational Transmission of Violence Theory.

\section{References}

Franklin, C. A., (2010). The Intergenerational Transmission of Intimate Partner Violence, Crime Victims' Institute, Criminal Justice Centre, Sam Houstan State University, [Online] Available: http://www.crimevictimsinstitute.org/documents/CVI_Intergenerational. pdf, (July 24, 2016)

Randawar, D. K. \& Jayabalan, S., (2013). Wife Battering-A Malaysian Perspective", Proceedings of the Colloquium o Administrative Science and Technology. COAST 2013

Diduck, A. \& Kaganas, F., (2006). Family Law, Gender and the State: Text, Cases and Materials (2nd. Ed.). North America: Hart

${ }_{12}$ NS/RPM/1005/031 Passed by the National Assembly on 16 September 2005 
Publishing

Dutton, D. G., (2001). Men who were abused as children are more likely to batter their wives, In J.D. Lloyd (Eds.), Family Violence, (pp.85) United States of America: Greenhaven Press Inc.

Lockton, D., \& Ward, R., (1997). Domestic Violence. Great Britain: Cavendish Publishing Limited.

Douglas, G., (2001). An Introduction to Family Law. New York: Oxford University Press

Schneider, E. M., (2008). Domestic Violence Law Reform in the Twenty-First Century: Looking Back and Looking Forward. Family Law Quaterly/0014729X, 20080901

Freeman, M., (2007). Understanding Family Law (1st. Ed.). London: Sweet \& Maxwell

Dobash, R. E., \& Dobash, R., (1979). Violence Against Wives. United States of America: The Free Press a Division of Macmillan Publishing.

Hashim, I. H. M., \& Endut, N., (2003-2004). Final Report, A psychosocial study on wives experiencing domestic violence, School of Social Sciences, University Sains Malaysia Pulau PinangUSM Short-Term Grant

Jasinski, J. L., (2001). Theoretical Explanations for Violence Against Women, In Renzetti, C. M., Edleson, J. L. \& Bergen, R. K., (Eds.), Sourcebook on Violence Against Women, (pp.5) California: Sage Publications.

Gosselin, D. K., (2003). Heavy Hands An Introduction to the Crimes of Family Violence. New Jersey: Prentice Hall.

Akers, R. L., (2002). A Social Learning Theory of Crime, In Cote, S., (Eds.), Criminological Theories: Bridging the Past to the Future, (pp.135-143) California: Sage Publications.

Wallace, H., (1999). Family Violence Legal, Medical, and Social Perspectives. California: Allyn \& Bacon.

Mignon, S. I., Larson, C. J., and Holmes, W. M., (2002). Family Abuse: Consequences, Theories and Responses, Boston: Allyn and Bacon.

Belknap. J., (2001) The Invisible Woman- Gender, Crime and Justice, (2nd ed.) Canada: Wadsworth Thomson Learning.

Malaysian Domestic Violence Act 1994

Malaysian Law Reform (Marriage \& Divorce) Act 1976 (Act 164) This Act is made applicable throughout Malaysia on 1 March 1982

Malaysian Islamic Family Law (Federal Territory) Act 1984 (IFLA 1984)

The Republic of Philippines, Anti-Violence Against Women and their Children Act 2004, Act No. 9262. [Online] Available: http://www.lawphil.net/statutes/repacts/ra2004/ra_9262_2004.html, (April 24, 2016)

Indian, Protection of Women From Domestic Violence Act 2005, [Online] Available: http://ncw.nic.in/acts/TheProtectionofWomen fromDomesticViolenceAct2005.pdf, (April 24, 2016)

Cambodia, Law on the Prevention of Domestic Violence and the Protection of Victims. [Online] Available: https://www.wcwonline.org/pdf/ lawcompilation/Cambodia_dv_victims2005.pdf, (May 28, 2016)

Ehrensaft, M. K., Cohen, P., Brown, J., Smailes, E., Chen, H., Johnson, J. G., (2003), Intergenerational Transmission of Partner Violence: A 20-Year Prospective Study, Journal of Consulting and Clinical Psychology 2003, Vol. 71, No. 4, 741-753, [Online] Available: http://www.apa.org/pubs/journals/releases/ccp-714741.pdf, (July 24, 2016)

Hines, D. A., \& Saudino, K. J., (2002), Intergenerational Transmission of Intimate Partner Violence: A Behavioral Genetic Perspective, Trauma, Violence, \& Abuse, Vol. 3, No. 3, July 2002, 210-225, [Online] Available: http://www2.clarku.edu/faculty/dhines/Hines\% 20\&\%20Saudino\%202002-TVA\%20article.pdf, (July 24, 2016) 